\title{
Multiple stages of plant root calcification deciphered by chemical and micromorphological analyses
}

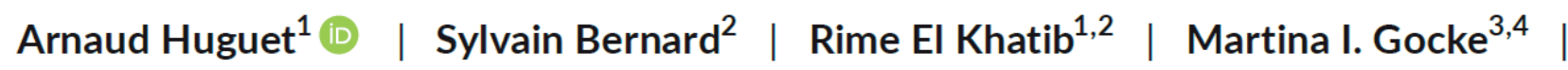
Guido L. B. Wiesenberg ${ }^{4}$ (D) | Sylvie Derenne ${ }^{1}$ 


\section{1}

\section{ABSTRACT}

2

3

Rhizoliths, i.e. roots fossilized by secondary carbonates, have been known for ages and are

4 increasingly used for paleoenvironmental reconstructions. However, knowledge about their

5 formation mechanisms remains limited. This study reports the mineralogical and chemical

6 characterization of rhizoliths at different stages of mineralization and fossilization in the Late

7 Pleistocene loess-paleosol sequence of Nussloch (SW Germany). Scanning electron

8 microscopy coupled with elemental mapping and ${ }^{13} \mathrm{C}$ solid-state nuclear magnetic resonance

9 were used to concomitantly characterize the mineral and organic matter of the rhizoliths.

10 These joint analyses showed for the first time that large rhizoliths are not necessarily remains

11 of single large roots, but consist of numerous microrhizoliths as remains of fine roots, formed

12 mainly by calcium carbonates with only low amounts of $\mathrm{Mg}$ and $\mathrm{Si}$. They further revealed

13 that the precipitation of secondary carbonates occurs not only around, but also within the plant 14 root and that fossilization leads to the selective preservation of recalcitrant root biopolymers -

15 lignin and suberin. The precipitation of secondary carbonates was observed to occur first 16 around fine roots, the epidermis acting as a first barrier, and then within the root, within the 17 cortex cells and even sometimes around the phloem and within the xylem. This study suggests 18 that the calcification of plant roots starts during the lifetime of the plant and continues after its 19 death. This has to be systematically investigated to understand the stratigraphic context before 20 using (micro)rhizoliths for paleoenvironmental reconstructions in terrestrial sediments.

22 Keywords: rhizoliths; SEM; ${ }^{13} \mathrm{C}$ NMR; loess sediments; secondary carbonates; organic 23 matter; paleoenvironment 


\section{Introduction}

Rhizoliths have been ascribed different names, e.g. root casts; rhizocretions; tubular fossils (Klappa, 1980), and may exhibit different morphologies and sizes (up to several $\mathrm{cm}$ in diameter and several meters length; Zamanian et al., 2016). These organo-sedimentary structures are common in sandy and silty calcareous soils and sediments (Becze-Deák et al., 1997) and can be highly abundant in loess (Gocke et al., 2011) and desert sands (Sun et al., 2020). In addition to terrestrial settings, rhizoliths were also observed in former lacustrine environments (e.g. Sun et al., 2019a) and marine settings (Jones and Ng, 1988).

Rhizoliths have been used as proxies for paleoenvironmental reconstructions over different geological time scales based mainly on macro- and micromorphological studies (Becze-Deák et al., 1997; Barta, 2011) or stable carbon and oxygen isotope analyses (e.g. Kuleshov and Gavrilov, 2001). The large number of applications of these objects include understanding of past hydrological conditions (Li et al., 2015a) and vegetation composition (e.g. Koeniger et al., 2014) or pedogenesis (Driese and Mora, 1993).

Rhizoliths in loess-paleosol sequences are considered as important Quaternary paleoenvironmental archives (Becze-Deák et al., 1997). Several tools have been applied for paleoenvironmental reconstructions in such sequences, including stable isotopes $\left(\delta^{13} \mathrm{C}\right.$ and $\left.\delta^{18} \mathrm{O}\right)$ of carbonates, pollen and bulk organic matter (OM) and specific compounds including lipid biomarkers (Pustovoytov and Terhorst, 2004; Frechen et al., 2007; Antoine et al., 2009; Zech et al., 2012). The underlying assumption of such studies is that the organic/inorganic signals present in sediments and paleosols were formed synsedimentarily and synpedogenically, respectively. Nevertheless, deep-rooting plants have the ability to penetrate sediments to a depth of several meters (Canadell et al., 1996). This was notably observed in several loess-(paleo)soil and sand-(paleo)soil sequences in Central and Southeast Europe (e.g. Gocke et al., 2014a), with high abundances of recent and fossilized roots (rhizoliths) as well 
53 as root-derived biopores down to several meters depth below the recent soil or associated 54 paleosol. The post-sedimentary incorporation of root-derived OM can lead to a large overprint of the initial signal in loess sediments, as shown for example for lipid biomarkers (e.g. $n$ alkanes, fatty acids, GDGTs; Huguet et al., 2013; Gocke et al., 2014b). The presence of carbonate rhizoliths in loess settings can therefore bias paleoenvironmental reconstructions. Corresponding data have to be interpreted with caution, as only limited knowledge about their formation mechanisms is available (e.g. Klappa, 1980; Gocke et al., 2011, 2014a, b; Li et al., 2015b; Sun et al., 2019a; Brazier et al., 2020).

It is generally assumed that root fossilization is controlled or induced by complex organicinorganic interactions at the plant level (Klappa, 1980; Jaillard et al., 1991; Kautz et al., 2013; characterization of roots at different stages of fossilization that have been sampled at different depths $(2.15 \mathrm{~m}, 3.5 \mathrm{~m}, 4 \mathrm{~m}$ and $8 \mathrm{~m}$ depth) from the extensively studied Late Pleistocene loess-paleosol sequence of Nussloch (SW Germany) (e.g. Antoine et al., 2009; Gocke et al., 2011; Zech et al., 2012; Huguet et al., 2013). The samples were chosen on the basis of their representativeness of the rhizoliths encountered along the Nussloch profile.

Scanning electron microscopy (SEM) and solid-state ${ }^{13} \mathrm{C}$ Nuclear Magnetic Resonance carbonate rhizoliths of different sizes in terrestrial loess sediments. 


\section{Materials and methods}

\subsection{Study site and sampling}

Recent and calcified roots were collected from a late Pleistocene loess-palaeosol sequence at the open cast mine of HeidelbergCement AG, Nussloch, SW Germany $\left(49.19^{\circ} \mathrm{N}, 8.43^{\circ} \mathrm{E}\right.$, $217 \mathrm{~m}$ above sea level), as described in detail by Gocke et al. (2010, 2011, 2014a, b). The sampled profile comprises $13.1 \mathrm{~m}$ of loess and soil units, including the recent soil, with 3 main paleosols and 14 incipient paleosols (Gocke et al., 2014b). At the top of the profile, the recent soil is developed as $0.6 \mathrm{~m}$ thick Vertic Cambisol Calcaric Siltic (Gocke et al., 2013). The present vegetation, related to living roots, consists of natural broad-leaf forest and nonnative robinia (Robinia pseudoacacia) as well as smaller shrubs and herbaceous plants and was described in detail by Gocke et al. (2013). It should be noted that present plant species were most likely not the dominant plants over the past decades or centuries due to former agricultural use. Rhizoliths at Nussloch were formed during various phases throughout the Holocene, with ages between 3 and 10 kyr (Pustovoytov and Terhorst, 2004; Frechen et al., 2007; Gocke et al., 2011) and were derived from roots of unknown trees or shrubs (likely hazel, oak, beech and alder; Gocke et al., 2013). They occur continuously from the recent soil to $8.8 \mathrm{~m}$ depth, with frequencies reaching up to $196 \mathrm{~m}^{-2}$ at $2.55 \mathrm{~m}$, and are also present below $10 \mathrm{~m}$ underneath a major paloeosol (Lohne Soil) in lower frequencies $\left(\leq 12 \mathrm{~m}^{-2}\right.$; Gocke et al., 2014a). They can be found in various shapes and sizes (diameter between a few mm to ca. 5 cm and length from mm to several m; Gocke et al., 2011).

Three types of samples were collected in Nussloch for comparison of the organo-mineral structure of the roots: (i) present vegetation (including Robinia pseudoacacia); (ii) initially calcified roots and (iii) rhizoliths. Initially calcified roots correspond to living roots with a thin $(<1 \mathrm{~mm})$ powdery carbonate coating on their surface. In contrast, samples termed as "rhizoliths" are fully carbonated roots with scarce or no root remains visible to the naked eye. 
104 Preparation of the Nussloch profile for calcified root collection implied removing at least 1 $105 \mathrm{~m}$ of material from the top and the side of the profile, respectively, and was followed by 106 counting of roots, root-related biopores and rhizoliths on horizontal levels (Gocke et al., 107 2014b). Rhizoliths were selected for sampling in several depth intervals where no or low 108 numbers of visible recent roots were observed in the surrounding loess, i.e. at $2.15 \mathrm{~m}, 3.5 \mathrm{~m}, 4$ $109 \mathrm{~m}$ and $8.8 \mathrm{~m}$ depth. Samples were collected and prepared as previously described (Gocke et 110 al., 2014b). Briefly, at each depth, intact loess cores were obtained using plastic rings with an 111 inner diameter of $20 \mathrm{~cm}$ and a height of $10 \mathrm{~cm}$. Cores were air-dried, covered with alumina 112 foil and kept at a cool, dry place until further preparation. After having removed the plastic 113 ring, the uppermost $1 \mathrm{~cm}$ and outermost $1 \mathrm{~cm}$ of loess material was removed to avoid any 114 contamination. Then, the core was cut into concentric slices from the outer parts to the 115 interior, with the rhizolith at its center (Gocke et al., 2014b) using a ceramic knife. The 116 rhizolith was separated from the surrounding loess by tweezers and a brush, and was then 117 ground and homogenized (Gocke et al., 2011) or kept as intact rhizoliths for scanning electron 118 microscopy.

119 Last, a loess interval at $10.4 \mathrm{~m}$ depth was selected for sampling the so-called "initially 120 calcified roots". The source vegetation of these fine roots is unknown, even though several 121 shrub species (mainly Buddleja $s p$.) were growing at the profile wall at ca. $8-10 \mathrm{~m}$ depth 122 below the recent soil. Initially calcified roots may also be present in upper layers of the 123 Nussloch sequence, but could not be discovered during profile preparation. Therefore, the $124 \quad 10.4 \mathrm{~m}$ horizon should only be considered as a typical depth interval, where roots at an initial 125 stage of calcification were collected. The initially calcified roots were air-dried and then 126 divided into two pieces, one of which was ground and homogenized, while the other was kept 127 as intact sample. 


\subsection{Electron microscopy}

Root and rhizolith samples were impregnated with epoxy resin, cross-sectioned perpendicular to their longitudinal direction, polished and gold-coated for scanning electron microscopy (SEM) investigations using a Zeiss Sigma microscope operating at the Laboratoire de Geologie (ENS-Paris). Backscattered electron imaging (BEI) was carried out at $10 \mathrm{kV}$ and a working distance of $9.4 \mathrm{~mm}$ using an AsB detector. Energy Dispersive X-ray Spectrometry (EDXS) micro-analyses were performed using INCA SmartMapTM software. Elements typically encountered in secondary carbonates and surrounding loess $(\mathrm{Ca}, \mathrm{O}, \mathrm{Al}$, $\mathrm{Mg}, \mathrm{Si}$ ) were traced in this study.

\subsection{Solid state ${ }^{13} \mathrm{C} N \mathrm{NR}$}

Roots from present vegetation and those with a thin carbonate crust were analyzed by ${ }^{13} \mathrm{C}$ NMR without any pre-treatment. In contrast, rhizoliths were treated with $3 \mathrm{M} \mathrm{HCl}$ to remove carbonates which would interfere with the organic carbon signal during analysis, rinsed with ultrapure water and then frozen at $-20{ }^{\circ} \mathrm{C}$ before being freeze-dried (Huguet et al., 2013). Samples were crushed in a ball mill before analysis.

Solid state ${ }^{13} \mathrm{C}$ cross polarization magic angle spinning nuclear magnetic resonance (CP MA NMR) was performed on a Bruker Avance 500 at $125 \mathrm{MHz}$ for ${ }^{13} \mathrm{C}$ using $4 \mathrm{~mm}$ diameter zircon rotors. Cross polarization allows the magnetization transfer from ${ }^{1} \mathrm{H}$ to ${ }^{13} \mathrm{C}$, leading to an increase in the signal/noise ratio. Magic angle spinning at $14 \mathrm{kHz}$ was used to reduce chemical shift anisotropy and to average dipolar interactions, hence decreasing the linewidths. The contact time between ${ }^{13} \mathrm{C}$ and ${ }^{1} \mathrm{H}$ in the CP MAS sequence was set to $1 \mathrm{~ms}$ and the repetition time to $1 \mathrm{~s}$. The NMR spectra were decomposed and integrated using Dmfit 
154 Kögel-Knabner, 2002; Lemma et al., 2007; Mathers et al., 2007): alkyl C = 0-45 ppm 155 (includes aliphatic and $\alpha$-amino $\mathrm{C}$ ); $\mathrm{O} / \mathrm{N}$-alkyl $\mathrm{C}=45-90 \mathrm{ppm}$ (includes methoxyl $\mathrm{C}$ and $\mathrm{C}$ in 156 amino groups); 90-110 pm = di-O-alkyl C (includes anomeric $\mathrm{C}$ in carbohydrates); 110-140

$157 \mathrm{ppm}=$ aromatic and unsaturated $\mathrm{C} ; 140-160 \mathrm{ppm}=$ phenolic $\mathrm{C} ; 160-220 \mathrm{ppm}=$ carbonyl C 158 (includes carboxylic $\mathrm{C}$, amides, ketones/aldehydes). More details regarding ${ }^{13} \mathrm{C}$ NMR and its 159 application to soil organic matter characterization can be found elsewhere (e.g. Knicker and 160 Nanny, 1997; Kögel-Knabner, 2002; Chukov et al., 2018).

161

\section{Results and discussion}

\subsection{Microscopic characterization of rhizoliths}

164 Rhizoliths of largely variable sizes (a few $\mathrm{cm}$ to $\mathrm{m}$ long) and diameters (a few $\mathrm{mm}$ to $\mathrm{cm}$ ) 165 were observed within the Nussloch loess-paleosol sequence, as shown for example at a depth 166 of $3.5 \mathrm{~m}$ (Fig. 1a). It was previously reported that rhizoliths with diameters $\geq 10 \mathrm{~mm}$ were 167 predominant between $2 \mathrm{~m}$ and $6 \mathrm{~m}$ depth and rhizoliths with diameters $<10 \mathrm{~mm}$ were mainly 168 observed below $6 \mathrm{~m}$ (Gocke et al., 2014a). Within some of the rhizoliths, the central part of 169 the rhizolith is hollow (Fig. 1b), indicating the absence of carbonates filling the void. Even 170 though some authors tried to classify root-related structures (Klappa, 1980) or more generally 171 secondary carbonate accumulations (Barta, 2011) in terrestrial settings based on their external 172 shapes, it remains difficult to classify the diversity of calcified root structures encountered in 173 Nussloch. The general term "rhizolith" will be used here in a broad sense to refer to root 174 traces, i.e., organo-mineral structures formed through fossilization of former roots.

175 Typical rhizoliths from Nussloch with diameters of $10-20 \mathrm{~mm}$ were analyzed for their 176 internal structure. Independent of the depth, Scanning Electron Microscopy (SEM) revealed 177 the presence of numerous small, fine roots encrusted by secondary carbonates within each 178 rhizolith (e.g. Fig. 1c, f; Supp. Fig. 1). Gocke et al. (2014a) previously performed X-ray 
179 microtomography scanning of one rhizolith collected at $3.5 \mathrm{~m}$ depth in Nussloch and observed

180 that the corresponding rhizolith contained three distinct, partially connected pores. These

181 small carbonate accumulations (diameter of $<1 \mathrm{~mm}$ ) were referred to as microrhizoliths based

182 on morphological comparison with larger rhizoliths (diameter mostly 3-20 mm, up to 100

$183 \mathrm{~mm}$; Gocke et al., 2014a). The present SEM results further show for the first time that,

184 independent of the depth, each rhizolith that was previously assumed to be one large

185 individual calcified root, rather consists of an assemblage of numerous "microrhizoliths",

186 which are only visible at the microscopic scale.

187 Most of these microrhizoliths roughly displayed a round shape and a central void (Fig. 1f,

$188 \mathrm{~g}$ ), indicative of the growth of the fine roots mainly in vertical direction, consistently with

189 previous observations (Gocke et al., 2011). A zoom on individual microrhizoliths reveals a

190 mosaic structure consisting of partially irregularly spread, almost concentrically arranged

191 pores and cells (Fig. 2b, c), which shows large similarities to the internal structure of recent

192 roots (Kutschera and Lichtenegger, 2002). Based on EDXS analysis, the mineral components

193 of the rhizoliths are mainly Ca-rich and Mg-poor carbonates (Fig. 3a).

194 In order to better constrain the different biomineralization processes leading to the

195 formation of the rhizoliths, the micro-elemental and -structural characteristics of

196 microrhizoliths were compared with those of (i) fresh fine roots from present vegetation at the

197 site (Robina pseudoacacia tree) and (ii) roots with a thin carbonate crust. These three types of

198 samples represent, in a simplified way, the different stages of the calcification process (Fig.

$1992)$.

200 Fresh, non-encrusted roots (Fig. 2h, i) show concentric layers of cells, with (i) a central 201 part (medulla) consisting of vascular tissues and (ii) an outer layer of cortical cells, which 202 represents the common buildup of living roots (Urry et al., 2016). The central part (Fig. 2i) is 203 characterized by secondary tissues with thick cell walls. Most of the structural characteristics 
204 of the fresh tree root are still present in the initially calcified root (Fig. 2e, f). Nevertheless, 205 some differences are observed between these two types of roots. The root with a thin 206 carbonate crust (Fig. 2d-f) is characterized by (i) a thinner layer of cortical cells and (ii) larger 207 diameter central cells in comparison with the fresh fine root. Such differences could reflect 208 the younger age of the initially carbonated root compared to the fresh one or might be species209 specific. Root growth and development was indeed observed to result in the formation of 210 thicker cell walls in the central part, improving the mechanical strength, flexibility and storage 211 capacity of the roots (Raven et al., 2000; Kraus and Bascunsuelo, 2009). It can also not be 212 excluded that a part of the structural variations between the fresh and initially calcified roots 213 are due to their different origins (tree vs. unknown shrubs, respectively), as every plant 214 species can display slightly distinctive root morphological features (e.g. Basconsuelo et al., 215 2011).

216 Initially calcified roots can also be distinguished from the fresh roots by the presence of 217 calcium carbonate in some of the cortex cells (Fig. 2e, f), showing that the calcification 218 process seems to initially occur within the cortical cells and not only as a coating at the 219 surface of the root. A preliminary stage is very likely the precipitation of calcium carbonate at 220 the surface of the roots, as a thin surficial carbonatic crust was observed after sampling of the 221 initially calcified roots in Nussloch (Fig. 2d), in agreement with previous observations 222 (Huguet et al., 2013). An immediate effervescence was noted when a few drops of 3M $\mathrm{HCl}$ 223 were added at the surface of the crust, confirming the carbonatic nature of the latter. By 224 combining these bulk and microscopic observations, we may assume that the calcification 225 process of the small roots is initiated outside the epidermis and thereafter or simultaneously 226 within the cortex cells.

227 A part of the initial cell and pore structure observed in the fresh root (Fig. 2h, i) was also 228 observed in microrhizoliths (Fig. 1d, e, g and Fig. 2c). Especially cortex cells filled by 
229 carbonates are still visible in these microstructures (Figs. $1 \mathrm{~g}$ and 2b), which is in agreement 230 with previous observations (Klappa, 1980; Jaillard et al., 1991; Owen et al., 2008; Cramer and 231 Hawkins, 2009). Nevertheless, in Nussloch, some of the microrhizoliths were entirely filled 232 by carbonates (e.g. the one highlighted in red in Fig. 1c). Most likely, the root cell structure is 233 preserved both in the cortical and central parts of the root (Fig. 1d, e) through the precipitation 234 of calcium carbonate (Fig. 3a). Within one single large rhizolith, numerous microrhizoliths 235 with different structures and preservation stages can be encountered. It may not be excluded 236 that all of the microrhizoliths detected at a given depth were not formed concomitantly. As we 237 did not observe any root-like concentric structures in the large rhizoliths (Fig. 1c), we can 238 exclude that a large root was responsible for the formation of the rhizolith. Either there were a 239 lot of fine roots growing inside the decaying large root after its depth or numerous fine roots 240 made use of the biopore that was surviving after the decay of a former root. In both cases, the 241 largely abundant fine roots may be subsequently exposed to Ca-rich solutions in the loess, 242 leading to the carbonate encrustation and fossilization of the former fine roots. In any case, 243 there must be a decoupling of loess sedimentation and formation of large rhizoliths as the 244 latter may have occurred at any point after the formation of the large biopore that was later 245 filled by microrhizoliths, which explains the different ${ }^{14} \mathrm{C}$ ages of rhizoliths observed by 246 Gocke et al. (2011) at Nussloch.

\subsection{Characterization of organic matter by ${ }^{13} \mathrm{C}$ NMR}

251 Fresh fine roots, initially calcified roots and rhizoliths collected at the Nussloch loess252 paleosol profile were analyzed by ${ }^{13} \mathrm{C}$ NMR to investigate the effect of calcification on the 253 composition of root organic matter. The ${ }^{13} \mathrm{C}$ NMR spectrum of $R$. pseudoacacia fine roots 
254 (Fig. 4a) presented in this study is similar to those spectra that were previously reported for 255 roots of various higher plants (Helfrich et al., 2006; Lemma et al., 2007; Mathers et al., 2007). 256 It was dominated by a signal ranging between 45 and $110 \mathrm{ppm}$ due to N/O-alkyl C. This 257 region comprised two main peaks (i) at $73 \mathrm{ppm}$, which can be derived from cellulose and 258 suberin, and (ii) at $105 \mathrm{ppm}$ indicative for anomeric $\mathrm{C}$ that can be related to hemicelluloses 259 and other carbohydrates (Baldock et al., 1992; Helfrich et al., 2006), with associated 260 shoulders or less intense peaks at 65,84 and $89 \mathrm{ppm}$. This is consistent with the fact that 261 macromolecules such as cellulose, non-cellulosic carbohydrates (hemicelluloses, polyoses, 262 pectines), cutin and suberin are major components of plant tissues, especially in primary cell 263 walls (Albersheim, 1976). The dominant peak in the aliphatic region (0-45 ppm) was 264 observed at $30 \mathrm{ppm}$, corresponding to methylene groups present in lipids (Preston and 265 Ripmeester, 1982; Baldock et al., 1992) and macromolecules such as suberin (Gil et al., 266 1997). Minor peaks between 25 and $35 \mathrm{ppm}$ are similarly attributed to aliphatic compounds 267 (Helfrich et al., 2006). Broad and less intense peaks were also visible at 120-130 and 150 ppm 268 in the aromatic and O-aryl regions, respectively, and are related to aromatic molecules such as 269 lignin and tannins. The contribution of the latter type of biopolymers is further supported by 270 the peak at $56 \mathrm{ppm}$, which can be related to methoxyl groups (Zech et al., 1989; Parfitt and 271 Newmann, 2000). The carbonyl C region was dominated by a broad peak at $174 \mathrm{ppm}$ that is 272 classically attributed to esters, carboxylic acids and amides, which can be found in lignin, 273 hemicelluloses, lipids and proteins (Wilson, 1987).

274 Only slight differences were observed between the ${ }^{13} \mathrm{C}$ NMR spectra of fresh and initially 275 calcified roots (Fig. 4a and b, respectively) in the 50-200 ppm region. In contrast to the fresh 276 roots (Fig. 4a), a decrease in the peak at $30 \mathrm{ppm}$ and associated shoulders between 25 and 35 $277 \mathrm{ppm}$ and a slight increase in the peak at $15 \mathrm{ppm}$ was noticed for the initially calcified roots 278 (Fig. 4b). ${ }^{13} \mathrm{C}$ NMR spectra of three rhizoliths $(2.15 \mathrm{~m}, 3.5 \mathrm{~m}$ and $4 \mathrm{~m}$ depth) collected at 
279 Nussloch were also recorded. However, the ${ }^{13} \mathrm{C}$ NMR signals of the rhizoliths collected at $2802.15 \mathrm{~m}$ and $3.5 \mathrm{~m}$ depth (e.g. Supp. Fig. 2) were not sufficiently resolved and the signal to 281 noise ratio was too low for a proper interpretation. Therefore, only the ${ }^{13} \mathrm{C}$ NMR spectrum of 282 the rhizolith collected at $4 \mathrm{~m}$ depth will be considered in the rest of this study. It exhibited 283 broader signals in the aliphatic, $\mathrm{O} / \mathrm{N}$-alkyl and carboxylic $\mathrm{C}$ regions (Fig. 4c) than those from 284 fresh and initially calcified roots (Fig. 4a, b).

285 In order to refine the comparison of the ${ }^{13} \mathrm{C}$ NMR spectra, the latter were deconvoluted and 286 then integrated, thus providing an estimation of the relative abundances of the different types 287 of $\mathrm{C}$ functional groups (expressed in $\%$ of the total area). Obvious changes in terms of relative 288 abundances of the different $\mathrm{C}$ functional groups were observed between the rhizolith on the 289 one hand and other roots on the other hand (Fig. 5). The rhizolith was characterized by a 290 strong decrease in the relative abundance of the $\mathrm{O} / \mathrm{N}$-alkyl and anomeric $\mathrm{C}$, along with a 291 strong increase in the relative abundance of the alkyl $\mathrm{C}$ and aromatic $\mathrm{C}$ in comparison with 292 the fresh and initially calcified roots. Such differences were reflected in the much higher 293 values of the alkyl-C/(O-alkyl + anomeric C) ratio for the rhizolith (0.60) than observed for 294 the fresh and initially calcified roots $(0.27$ and 0.21 , respectively). This ratio is classically 295 used as a proxy for soil OM degradation (Baldock et al., 1997), based on the fact that 296 carbohydrates (i.e. O-alkyl and anomeric C) are generally the first being affected by 297 decomposition, with a concomitant increase in the relative abundance of alkyl-C related 298 possibly due to the accumulation of molecules known as recalcitrant such as suberin and its 299 derivatives (Mathers et al., 2007; White, 2018). Therefore, ${ }^{13} \mathrm{C}$ NMR spectra of the different 300 type of roots reveal that preferential degradation of cellulose and non-cellulosic 301 polysaccharides as well as enrichment in suberin occurred during or after root calcification. 302 The latter option is consistent with the partial preservation of the cell wall structure of former 303 roots through calcification, as observed by SEM (Fig. 1d, e and Fig. 2f). 
304 The carboxyl $\mathrm{C}$ relative abundance strongly depends on the root or litter type during the 305 decomposition of OM, with an absence of trends reported for some samples (e.g. Wang et al., 306 2013) or an increase in the carboxyl C abundance for some others (e.g. Lemma et al., 2007). 307 Such an increase was partly attributed to the oxidative cleavage of lignin (Quideau et al., 308 2005) and/or to the accumulation of microbial fatty acids (Zech et al., 1997) during OM 309 decomposition. In Nussloch, no obvious difference in the carboxyl C abundance was observed 310 between rhizoliths, fresh and initially calcified roots (Fig. 5). This might suggest that lignin 311 was not subjected to major degradation during root calcification. This is consistent with the 312 limited fungal activity observed along most of the Nussloch sedimentary profile according to 313 phospholipid fatty acids biomarker analyses (Gocke et al., 2017), as fungi are considered to 314 play a major role in lignin degradation ( $\mathrm{Su}$ et al., 2018). Alternatively and/or 315 complementarily, lignin might be preferentially preserved during calcification due to the 316 degradation of more easily degradable substance classes such as sugars or fatty acids 317 (Marschner et al., 2018). This is supported by the relative increase in aromatic C for rhizoliths 318 vs. fresh and initially calcified roots (Fig. 5), which may be explained by the higher intrinsic 319 chemical recalcitrance of this biopolymer vs. other compounds such as carbohydrates (Rasse 320 et al., 2005).

321 Nevertheless, one should keep in mind that preservation of specific OM components in 322 soils or sediments is dependent not only on their chemical nature but also on physical and 323 environmental parameters (e.g. Derenne and Knicker, 2000). Consequently, in the case of the 324 rhizoliths, the nature of the mineral matrix and the environmental conditions reflect the time 325 of their formation, which is consistent with the study of Brazier et al. (2020), who observed a 326 close relationship of $\mathrm{Ca}$ and $\mathrm{Sr}$ isotopes of rhizoliths with the recent soil at Nussloch.

327 In conclusion, ${ }^{13} \mathrm{C}$ NMR showed that $\mathrm{OM}$ is partially preserved during the formation of 328 calcified roots in Nussloch, with a selective enrichment in recalcitrant and abundant root 
329 biopolymers such as lignin and suberin. This can be related to the good preservation of the 330 cell wall structure observed by electron microscopy (Figs. 1-3). Altogether, ${ }^{13} \mathrm{C}$ NMR and 331 SEM analyses suggest that the fossilization of the root by calcium carbonates was initiated 332 during the same time interval as the formation of root organic tissues (during the lifetime of 333 the root) and pursued shortly thereafter, preventing the loss of the root cell structure and 334 major degradation of OM. This is consistent with ${ }^{14} \mathrm{C}$ dating of one rhizolith from Nussloch 335 collected at $1.5 \mathrm{~m}$ depth, which revealed that both carbonatic and organic $\mathrm{C}$ ages were in the 336 same order of magnitude $(3788 \pm 59$ years BP and $3150 \pm 59$ years BP, respectively), thus 337 arguing for the absence of postsegregational alteration (Gocke et al., 2011).

\subsection{Origin and formation of (micro)rhizoliths}

\subsubsection{Vegetation sources}

341 Grasses and herbaceous plants can be assumed to be potential sources of microrhizoliths 342 in the loess sequence of Nussloch (Gocke et al., 2014a), as some of these plants develop deep 343 roots (up to $2.6 \mathrm{~m}$; Canadell et al., 1996), have more fine roots than trees (Jackson et al., 344 1997) and can represent the dominant vegetation at some time periods. Nevertheless, when 345 both rhizoliths and microrhizoliths are abundant in sediments (e.g. between 1 and $6 \mathrm{~m}$ depth 346 in Nussloch; Gocke et al., 2014a), it is difficult to constrain the main vegetation source of 347 these calcified structures. In this case, microrhizoliths may originate not only from herbaceous 348 plants but also from fine roots of trees and shrubs based on lipid analyses (Gocke et al., $3492010 a, 2014 b$ ) as these can have much deeper root systems up to several meters depth 350 (Canadell et al., 1996). The large, nearly round shaped structure of all rhizoliths (e.g. Fig. 1b) 351 suggests that e.g. taproots of trees formed these structures that could be traced over several 352 meters depth within the profile. It is less likely that other organisms than plants produce such 
353 connected structures with branches similar to those in recent root systems and previously

354 visualized by computed tomography measurements (Gocke et al., 2014b).

\subsubsection{Proposed formation mechanism of calcified roots}

A formation mechanism of microrhizoliths and large rhizoliths in terrestrial loess

358 sediments can be proposed based on the results from the present study in Nussloch combined 359 with those of previous investigations. Three main steps can be envisioned:

360 1) After or during the growth of fine roots, a carbonate coating can develop on their 361 surface by precipitation of calcium carbonate, as suggested by bulk ( $\mathrm{HCl}$ treatment) 362 and microscopic analyses of initially calcified roots (Fig. 2d, e, f). The initiation of the 363 calcification is directly related to rhizosphere processes and to the associated high 364 microbial activity (Jones, 1998). Roots increase acidity in the surrounding 365 soil/sediment by releasing $\mathrm{CO}_{2}$ and exudates, which contains especially organic acids (Klappa, 1980). Primary $\mathrm{CaCO}_{3}$ from soil/sediment is dissolved and $\mathrm{Ca}^{2+}$ is being transferred in solution towards the root. At the root surface not all calcium, magnesium, strontium and other elements might be taken up by the plants as nutrients and can be precipitated as secondary carbonates at the root surface (Barta, 2011). This is supported by the high $\mathrm{CO}_{2}$ concentration in the vicinity of the root due to root and microbial respiration (Hinsinger et al., 2003). In addition, $\mathrm{Ca}^{2+}$ and $\mathrm{Sr}^{2+}$ from topsoils can be taken up by plant roots and translocated towards larger depths in loess-paleosol sequences as described by Brazier et al. (2020). Simultaneously, or after precipitation of the carbonate coating on the surface of the fine roots, surplus calcium can be precipitated as calcium carbonate within the cortex cells when fine roots are still alive, as observed in Nussloch (Fig. 2g). Some of the fine roots may be totally infilled by calcium carbonate, with precipitation around phloem and even xylem cells, as seen for 
378 some of the Nussloch microrhizoliths (Fig. 3b). This disproves the assumption of some 379 authors that rhizoliths (or similar fossils like rhizogenic calcretes) are formed 380 exclusively after death and during or after decay of the root (e.g. Joseph and $381 \quad$ Thrivikramaji, 2006). 399 The agglomeration of microrhizoliths may be seen as a hotspot for nutrient and water 400 acquisition as well as microbial activity (Jones, 1998), and may promote the active 401 growth of new fine roots in the cavities of former large roots or potentially in-between 402 (micro-)rhizoliths, especially if they are incompletely fossilized and thus provide voids precipitate in voids between several of the fine roots. This is supported by the presence of a large number of microrhizoliths within one "large" rhizolith from Nussloch with precipitated carbonate in-between individual microrhizoliths (Fig. 1c, f; Supp. Fig. 1). 
403 for new root growth, which was similarly observed, e.g., in a sandy profile of Sopron 404 (NW Hungary; Huguet et al., 2013). Especially in deeper parts of the soil, biopores 405 often serve as places for renewed root growth (White and Kirkegaard, 2010). After the 406 death of the plants, large biopores formed by decaying roots may remain stable for 407 millennia in fine-textured sediments such as loess (Kerényi, 2015). Also in the profile 408 of Nussloch many biopores were observed throughout the whole sequence, i.e. in depth 409 intervals with high and low abundance of recent roots and rhizoliths, respectively (Gocke et al., 2014a). Consequently, it is likely in the Nussloch sequence that agglomeration of microrhizoliths occurs in biopores that were primarily produced by large tap-roots of shrubs and trees. Either during the decay of these large roots or at one point thereafter while still biopores were preserved, fine roots colonized the large biopore or decaying root, and subsequently formation of microrhizoliths occurred by the precipitation of calcium carbonate with only traces of $\mathrm{Mg}$ or Si (Fig. 3), whereas minerals like quartz, micas or feldspars derived from primary loess were only detected close to the outer rims of large rhizoliths (Gocke et al., 2011). Of course, it is possible that several generations of microrhizoliths can develop in one biopore of a diameter of several $\mathrm{cm}$, while some older microrhizoliths might serve as additional source of nutrients on top of the surrounding sediment (Brazier et al., 2020). Thus, the carbonate remains might be partially destructed as indicated by the different status of microrhizoliths within one large rhizolith, with (i) almost intact microrhizoliths presenting perfectly round shaped structures, (ii) partially calcified microrhizoliths and (iii) residual microrhizolith structures with no clear internal structure anymore (Fig. 1).

The assemblage of numerous microrhizoliths in biopores left behind after decay of former 426 larger roots led to the formation of larger rhizoliths, might have occurred during a large time 427 span starting with the development of large roots and biopores after their decay shortly after 
428 sedimentation and formation of microrhizoliths at later stages. Thus, large rhizoliths in 429 Nussloch are of Holocene age (3000-9000 yrs BP) and are much younger than surrounding 430 loess deposited mainly during the last glacial-interglacial cycle (ca. 20,000 yrs BP; Gocke et 431 al., 2011). A time lag of 2 kyrs between sediment deposition and its penetration by roots was 432 also observed in a Siberian loess-like sediment (Zech et al., 2007). Similarly, in dune sands 433 (NW China), rhizoliths were of younger age than surrounding soil (Sun et al., 2019b). Even 434 small calcified root cells can be formed much later than surrounding sediment $(>10$ kyrs for a 435 section close to Nussloch; Pustovoytov and Terhorst, 2004). Nevertheless, the time lag 436 between the formation of rhizoliths and the surrounding sediment will be much larger for 437 large roots compared to fine roots (several millennia vs. decades to centuries, respectively; 438 Gocke et al., 2014a). In Nussloch, several rhizoliths and microrhizoliths of different size, 439 morphology and thus very likely strongly differing age were observed within given 440 stratigraphic units, where the calcified structures were abundant (e.g. at $3.5 \mathrm{~m}$, Fig. 1a). This 441 complicates the interpretation of paleoenvironmental and paleoecological data derived from 442 (micro)rhizoliths and stresses the importance of fully understanding their formation in 443 terrestrial sediments.

\section{Conclusions}

446 The organo-mineral structure of roots at different mineralization stages, collected along the 447 Nussloch loess-palesol sequence, was documented using scanning electron microscopy and $448{ }^{13} \mathrm{C}$ solid nuclear magnetic resonance. The application of SEM and ${ }^{13} \mathrm{C}$ NMR, in combination 449 with previous results, allowed for the first time the establishment of a formation model for 450 (micro)rhizoliths and consequently the assemblage of numerous microrhizoliths resulting in 451 large rhizoliths: large rhizoliths were shown to consist of numerous microrhizoliths, formed 452 mainly by calcium carbonates with only low amounts of $\mathrm{Mg}$ and $\mathrm{Si}$. The precipitation of 
453 secondary carbonates was observed for initially calcified roots to occur first around the fine 454 root, the epidermis acting as a first barrier, and then within the root, within the cortex cells 455 and even sometimes around the phloem and within the xylem. Fossilization of large and fine 456 roots by secondary carbonates was shown to allow a good preservation of root cell structure 457 and selective enrichment of recalcitrant root biopolymers such as lignin and suberin, 458 suggesting that the formation of (micro)rhizoliths may be initiated during the lifetime of the 459 root and continues after its death. This has to be systematically determined before using 460 (micro)rhizoliths for paleoenvironmental or paleoecological reconstructions and interpreting 461 the corresponding data with confidence. Lipid (e.g. $n$-alkanes, GDGTs, fatty acids) and 462 compound-specific isotope analyses (including radiocarbon dating) could be used to better 463 constrain this context.

464

465

466

467

468

469

470

471

472

473

474

475

476

477

478

479

480

481

482

483

484

485

486

487

488

489 


\section{References}

Albersheim, P. (1976). The primary cell wall. In: Plant Biochemistry, Bonner and Varner eds. 3rd Edition, Academic Press, New York, 225-274.

Antoine, P., Rousseau, D.D., Moine, O., Kunesch, S., Hatté, C., Lang, A., Tissoux, H., Zöller, L. (2009). Rapid and cyclic aeolian deposition during the Last Glacial in European loess: a high-resolution record from Nussloch, Germany. Quaternary Science Reviews, 28, 29552973.

Baldock, J.M., Oades, J.M., Waters, A.G., Peng, X., Vassallo, A.M., Wilson, M.A. (1992). Aspects of the chemical structure of soil organic materials as revealed by solid-state ${ }^{13} \mathrm{C}$ NMR spectroscopy. Biogeochemistry, 16, 1-42.

Baldock, J.A., Oades, J.M., Nelson, P.N., Skene, T.M., Golchin, A., Clarke, P. (1997). Assessing the extent of decomposition of natural organic materials using solid state ${ }^{13} \mathrm{C}$ NMR spectroscopy. Australian Journal of Soil Research, 35, 1061-1083.

Barta, G. (2011). Secondary carbonates in loess-paleosoil sequences: a general review. Central European Journal of Geosciences 3, 129-146.

Basconsuelo, S., Grosso, M., Molina, M.G., Malpassi, R., , Kraus, T., Bianco, C., 2011. Comparative root anatomy of papilionoid Legumes. Flora, 206, 799-807.

Becze-Deák, J., Langohr, R., Verrecchia, E. (1997). Small scale secondary CaCO3 accumulations in selected sections of the European loess belt: morphological forms and potential for paleoenvironmental reconstruction. Geoderma, 76, 221-252.

Bindschedler, S., Cailleau, G., Verrecchia, E. (2016). Role of fungi in the biomineralization of calcite. Minerals, 6, 41.

Brazier, J.-M., Schmitt, A.D., Gangloff, S., Pelt, E., Gocke, M.I., Wiesenberg, G.L.B. (2020). Multi-isotope approach $(\delta 44 / 40 \mathrm{Ca}, \delta 88 \mathrm{Sr}$ and $87 \mathrm{Sr} / 86 \mathrm{Sr})$ provides insights into rhizolith formation mechanisms in terrestrial sediments of Nussloch (Germany). Chemical Geology $545,119641$.

Canadell, J., Jackson, R.B., Ehleringer, J.R.,Mooney, H.A., Sala, O.E., Schulze, E.D. (1996). Maximum rooting depth of vegetation types at the global scale. Oecologia, 108, 583-595.

Chukov, S.N., Lodygin, E.D., Abakumov (2018). Application of 13C NMR spectroscopy to the study of soil organic matter: A review of publications. Eurasian Soil Science 51, 889900.

Cramer, M.D., Hawkins, H.J (2009). A physiological mechanism for the formation of root casts. Palaeogeography, Palaeoclimatology, Palaeoecology, 274, 125-133.

Derenne, S., Knicker, H. (2000). Chemical structure and preservation processes of organic matter in soils and sediments. Organic Geochemistry, 31, 607-608.

Ding, Y., Leppälammi-Kujansuu, J., Helmisaari, H.-S. (2019). Fine root longevity and belowand aboveground litter production in a boreal Betula pendula forest. Forest Ecology and Management, 431, 17-25.

Driese, S.G., Mora, C.I. (1993). Physico-chemical environment of pedogenic carbonate formation in Devonian vertic palaeosols, central Appalachians, USA. Sedimentology, 40, 199-216.

Frechen, M., Terhorst, B., Rähle,W. (2007). The Upper Pleistocene loess/palaeosol sequence from Schatthausen in North Baden-Württemberg. Quaternary Science Journal, 56, 212-227.

Fröberg, M. (2012). Residence time of fine-root carbon using radiocarbon measurements of samples collected from a soil archive. Journal of Plant Nutrition and Soil Science, 175, 4648.

Gil, A.M., Lopes, M., Rocha, J., Pascoal Neto, C. (1997). A ${ }^{13}$ C solid state nuclear magnetic resonance spectroscopic study of cork cell wall structure: the effect of suberin removal. International Journal of Biological Macromolecules, 20, 293-305. 
540 Gocke, M., Wiesenberg, G.L.B., Pustovoytov, K., Kuzyakov, Y. (2010). Rhizoliths in loess 541 evidence for post-sedimentary incorporation of root-derived organic matter in terrestrial 542 sediments as assessed from molecular proxies. Organic Geochemistry, 41, 1198-1206.

543

544

545

546

547

548

549

550

551

552

553

554

555

556

557

558

559

560

561

562

563

564

565

566

567

568

569

570

571

572

573

574

575

576

577

578

579

580

581

582

583

584

585

586

587

588

589

Gocke, M., Pustovoytov, K., Kühn, P., Wiesenberg, G.L.B., Löscher, M., Kuzyakov, Y. (2011). Carbonate rhizoliths in loess and their implications for paleoenvironmental reconstruction revealed by isotopic composition: $\delta^{13} \mathrm{C},{ }^{14} \mathrm{C}$. Chemical Geology, 283, 251260.

Gocke, M., Kuzyakov, Y., Wiesenberg, G.L.B. (2013). Differentiation of plant derived organic matter in soil, loess and rhizoliths based on $n$-alkane molecular proxies. Biogeochemistry, 112, 23-40.

Gocke, M., Gulyás, S., Hambach, U., Jovanović, M., Kovács, G., Marković, S.B., Wiesenberg, G.L.B. (2014a). Biopores and root features as new tools for improving paleoecological understanding of terrestrial sediment-paleosol sequences. Palaeogeography, Palaeoclimatology, Palaeoecology, 394, 42-58.

Gocke, M., Peth, S., Wiesenberg, G.L.B. (2014b). Lateral and depth variation of loess organic matter overprint related to rhizoliths revealed by lipid molecular proxies and X-ray tomography. Catena, 112, 72-85.

Gocke, M.I., Huguet, A., Derenne, S. Kolb, S., Dippold, M., Wiesenberg, G.L.B. (2017). Disentangling interactions between microbial communities and roots in deep subsoil. Science of the Total Environment, 575, 135-145.

Graça, J. (2015). Suberin: the biopolyester at the frontier of plants. Frontiers in Chemistry, 3, 62. https://doi.org/10.3389/fchem.2015.00062

Helfrich, M., Ludwig, B., Buurman, P., Flessa, H. (2006). Effect of land use on the composition of soil organic matter in density and aggregate fractions as revealed by solidstate 13C NMR spectroscopy. Geoderma, 136, 331-341.

Hinsinger, P., Plassard, C., Tang, C., Jaillard, B. (2003). Origins of root-mediated pH changes in the rhizosphere and their responses to environmental constraints: a review. Plant and Soil 248, 43-59.

Huguet, A., Wiesenberg, G.L.B., Gocke, M., Fosse, C., Derenne, S. (2012). Branched tetraether membrane lipids associated with rhizoliths in loess: rhizomicrobial overprinting of initial biomarker record. Organic Geochemistry, 43, 12-19.

Huguet, A., Gocke, M., Derenne, S., Fosse, C., Wiesenberg, G.L.B. (2013). Root-associated branched tetraether source microorganisms may reduce estimated paleotemperatures in subsoil. Chemical Geology, 356, 1-10.

Jackson, R.B.,Mooney, H.A., Schulze, E.D. (1997). A global budget for fine root biomass, surface area, and nutrient contents. Proceedings of the National Academy of Sciences of the United States of America, 94, 7362-7366.

Jaillard, B., Guyon, A., Maurin, A.F. (1991). Structure and composition of calcified roots, and their identification in calcareous soils. Geoderma, 50, 197-210.

Jones, D.L. (1998). Organic acids in the rhizosphere - a critical review. Plant and Soil, 205, $25-44$.

Jones, B., Ng, K.-C. (1988). The structure and diagenesis of rhizoliths from Cayman Brac, British West Indies. Journal of Sedimentary Research 58, 457-467.

Joseph, S., Thrivikramaji, K.P. (2006). Rhizolithic calcrete in Teris, southern Tamil Nadu: origin and paleoenvironmental implications. Journal of the Geological Society of India 65, $158-168$

Kerényi, A. (2015). Chapter 25. Loess Features on Tokaj Hill, in: Lóczy, D. (Ed.), Landscapes and Landforms of Hungary. Springer, Heidelberg, pp. 219-226.

Klappa, C.F. (1980). Rhizoliths in terrestrial carbonates: classification, recognition, genesis, and significance. Sedimentology, 27, 613-629. 
590 Knicker, H., Nanny, M.A. (1997). Nuclear magnetic resonance spectroscopy: Basic theory 591 and background. In: NMR spectroscopy in environmental science and technology. Nanny, 592 M.A., Minear, R.A., Leenheer, J.A. (Eds). Oxford University Press, London, 3-15.

Koeniger, P., Barta, G., Thiel, C., Bajnóczi, B., Novothny, Á., Horváth, E., Techmer, A., Frechen, M. (2014). Stable isotope composition of bulk and secondary carbonates from the Quaternary loess-palaeosol sequence in Sütto, Hungary. Quaternary International, 319, 3849.

Kögel-Knabner, I. (2002). The macromolecular organic composition of plant and microbial residues as inputs to soil organic matter. Soil Biology \& Biochemistry, 34, 139-162.

Kraus, T., Basconsuelo, S. (2009). Secondary root growth in Rhynchosia edulis Griseb. (Leguminosae): origin of cambia and their products. Flora, 204, 635-643.

Kuleshov, V.N., Gavrilov, Y.O. (2001). Isotopic composition $\left(\delta^{13} \mathrm{C}, \delta^{18} \mathrm{O}\right)$ of carbonate concretions from terrigenous deposits in the Northern Caucasus. Lithology and Mineral Resources, 36, 160-163.

Kutschera L., Lichtenegger E. (2002). Wurzelatlas mitteleuropäischer Waldbäume und Sträucher. Stocker Leopold Verlag, 604 pp.

Lemma, B., Nilsson, I., Kleja, D.B., Olsson, M., Knicker, H. (2007). Decomposition and substrate quality of leaf litters and fine roots from three exotic plantations and a native forest in the southwestern highlands of Ethiopia. Soil Biology and Biochemistry, 39, 23172328.

Li, Z., Wang, N., Li, R., Ning, K., Cheng, H., Zhao, L. (2015a). Indication of millennial-scale moisture changes by the temporal distribution of Holocene calcareous root tubes in the deserts of the Alashan Plateau, Northwest China. Palaeogeography Palaeoclimatology Palaeoecology, 440, 496-505.

Li, Z., Wang, N., Cheng, H., Ning, K., Zhao, L., Li, R. (2015b). Formation and environmental significance of late Quaternary calcareous root tubes in the deserts of the Alashan Plateau, northwest China. Quaternary International, 372, 165-174.

Massiot, D., Fayon, F., Capron, M., King, I., Le Calvé, S., Alonso, B., Durand, J.-O., Bujoli, B., Gan, Z., Hoatson, G. (2002). Modelling one- and two-dimensional solid-state NMR spectra. Magnetic Resonance in Chemistry, 40, 70-76.

Marschner B, Brodowski S, Dreves A, Gleixner, G., Gude, A., Grootes, P.M., Hamer, U., Heim, A., Jandl, G., Ji, R., Kaiser, K., Kalbitz, K., Kramer, C., Leinweber, P., Rethemeyer, J., Schäffer, A., Schmidt, M.W.I., Schwark, L., Wiesenberg, G.L.B. (2008). How relevant is recalcitrance for the stabilization of organic matter in soils? Journal of Plant Nutrition and Soil Science 171, 91-110.

Mathers, N.J., Jalota, R.K., Dalal, R.C., Boyd, S.E. (2007). ${ }^{13}$ C-NMR analysis of decomposing litter and fine roots in the semi-arid Mulga Lands of southern Queensland. Soil Biology \& Biochemistry, 39, 993-1006.

Nascimento, D.L., Batezelli, A., Ladeira, F.S. (2019). The paleoecological and paleoenvironmental importance of root traces: Plant distribution and topographic significance of root patterns in Upper Cretaceous paleosols. Catena 172, 789-806.

Owen, R.A., Owen, R.B., Renaut, R.W., Scott, J., Jones, B., Ashley, G.M. (2008). Mineralogy and origin of rhizoliths on the margins of saline, alkaline Lake Bogoria, Kenya Rift Valley. Sedimentary Geology, 203, 143-163.

Parfitt, R.L., Newman, R.H. (2000). ${ }^{13}$ C NMR study of pine needle decomposition. Plant Soil, 219, 273-278.

Preston, C.M., Ripmeester, J.A. (1982). Application of solution and solid-state ${ }^{13} \mathrm{C}$ NMR to four organic soils, their humic acids, fulvic acids, humins and hydrolysis residues. Canadian Journal of Spectroscopy, 27, 99-105. 
639 Pustovoytov, K., Terhorst, B. (2004). An isotopic study of a late Quaternary loess-paleosol 640 sequence in SW Germany. Revista Mexicana de Ciencas Geologicas, 21, 88-93.

641 Quideau, S.A., Graham, R.C., Oh, S.W., Hendrix, P.F., Wasylishen, R.E. (2005). Leaf litter 642 decomposition in a chaparral ecosystem, Southern California. Soil Biology \& Biochemistry, $643 \quad 37,1988-1998$.

644 Raven, P.H., Evert, R.F., Eichhorn, S.E. (2000). Biologie végétale, $6^{\text {th }}$ edition. De Boeck 645 646 647 648 649 650 651 652 653 654 655 656 657 658 659 660 661 662 663 664 665 666 667 668 669 670 671 Université editions.

Strand, A.E., Pritchard, S.G., McCormack, M.L., Davis, M.A., Oren, R. (2008). Irreconcilable differences: fine root lifespans and soil carbon persistence. Science, 319, 456-458.

Su, Y., Yu, X., Sun, Y., Wang, G., Chen, H., Chen, G. (2018). Evaluation of screened lignindegrading fungi for the biological pretreatment of corn stover. Scientific Reports 8, 5385.

Sun, Q., Xue, W., Zamanian, K., Colin, C., Duchamp-Alphonse, S., Pei, W. (2019a). Formation and paleoenvironment of rhizoliths of Shiyang River Basin, Tengeri Desert, NW China. Quaternary International, 502, 246-257.

Sun, Q., Wang, H., Zamanian, K. (2019b). Radiocarbon age discrepancies between the carbonate cement and the root relics of rhizoliths from the Badain Jaran and the Tengeri deserts, Northwest China. Catena, 180, 263-270.

Sun, Q., Zamanian, K., Huguet, A., Fa, K., Wang, H. (2020). Characterization and formation of the pristine rhizoliths around Artemisia roots in dune soils of Tengeri Desert, NW China. Catena 193, 104633.

Urry, L.A., Cain, M.L., Wasserman, S.A., Minorsky, P.V., Reece, J.B. (2016). Campbell Biology, $11^{\text {th }}$ Edition, Chap. 35: Vascular plant structure, growth and development. Pearson Eds.

Wang, H., Liu, S., Wang, J., Shi, Z., Lu, L., Guo, W., Jia, H., Cai, D. (2013). Dynamics and speciation of organic carbon during decomposition of leaf litter and fine roots in four subtropical plantations of China. Forest Ecology and Management, 300, 43-52.

White, R.G., Kirkegaard, J.A. (2010). The distribution and abundance of wheat roots in a dense, structured subsoil-implications for water uptake. Plant, Cell \& Environment, 33, $133-148$.

White, K.E., Coale, F.J., Reeves III, J.B. (2018). Degradation changes in plant root cell wall structural molecules during extended decomposition of important agricultural crop and forage species. Organic Geochemistry, 115, 233-245.

Wilson, M.A. (1987). NMR Techniques and Applications in Geochemistry and Soil Chemistry. Pergamon Press, Oxford. 353 pp.

Zamanian, K., Pustovoytov, K., Kuzyakov, Y. (2016). Pedogenic carbonates: Forms and formation processes. Earth-Science Reviews, 157, 1-17.

Zech, W., Haumaier, L., Kögel-Knabner, I. (1989). Changes in aromaticity and carbon distribution of soil organic matter due to pedogenesis. Science of the Total Environment, 81/82, 179-186.

Zech, M., Rass, S., Buggle, B., Löscher, M., Zöller, L. (2012). Reconstruction of the late Quaternary paleoenvironments of the Nussloch loess paleosol sequence, Germany, using $n$ alkane biomarkers. Quaternary Research, 78, 226-235.

Zech, W., Senesi, N., Guggenberger, G., Kaiser, K., Lehmann, J., Miano, T.M., Miltner, A., Schroth, G. (1997). Factors controlling humification and mineralization of soil organic matter in the tropics. Geoderma, 79, 117-161.

Zech, M., Zech, R., Glaser, B. (2007). A 240,000-year stable carbon and nitrogen isotope record from a loess-like palaeosol sequence in the Tumara Valley, Northeast Siberia. Chemical Geology, 242, 307-318. 

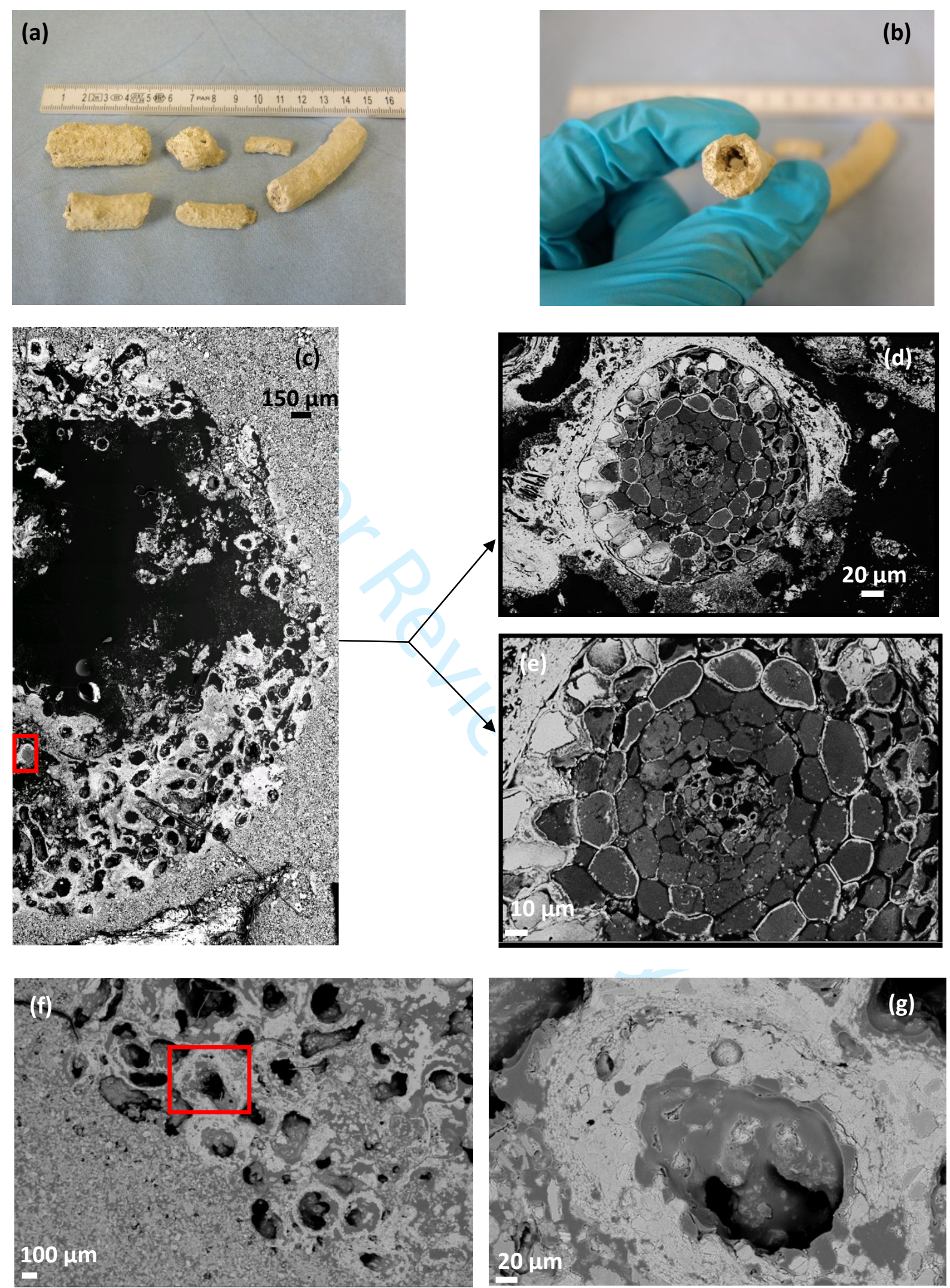

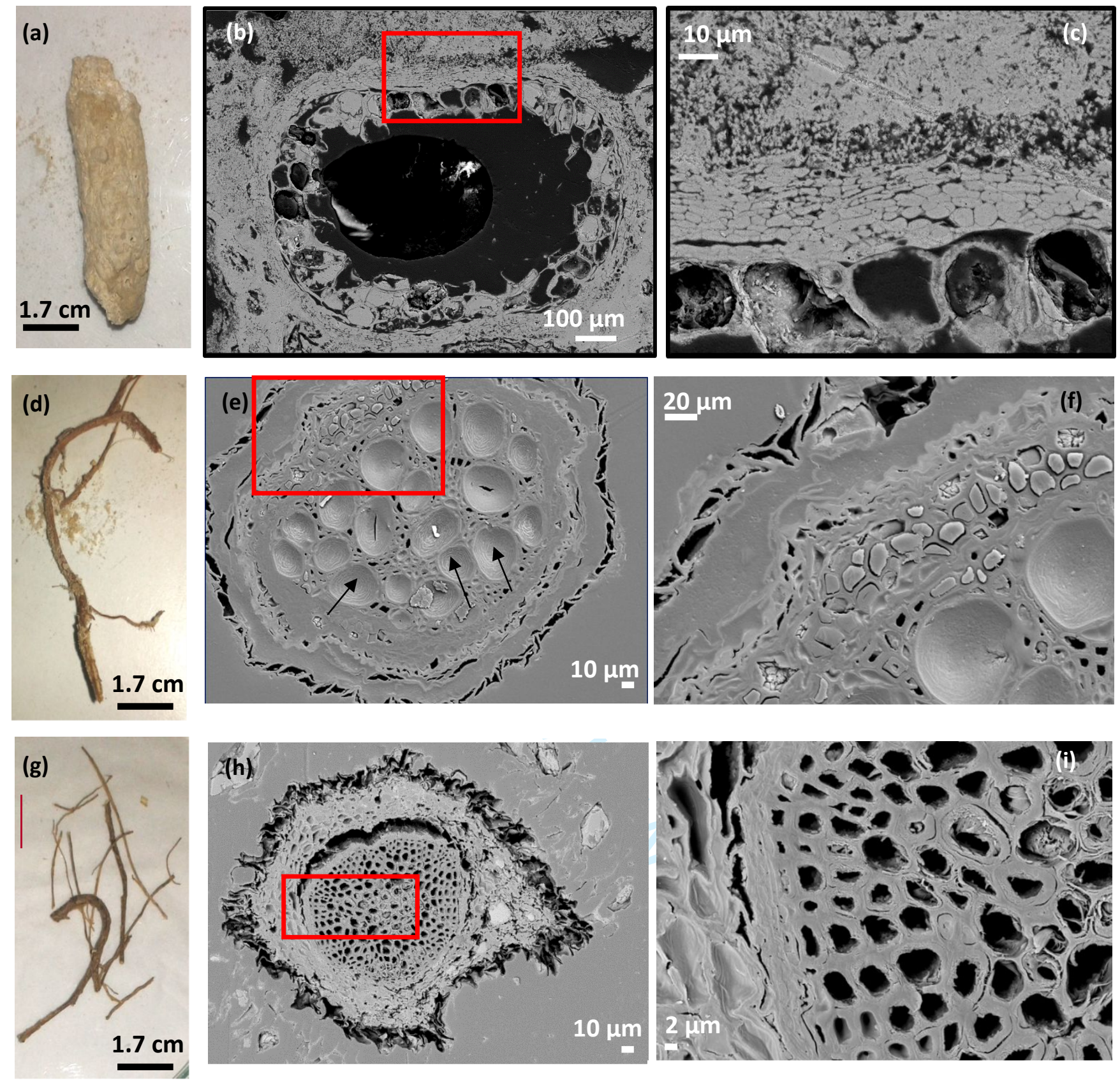
(a)
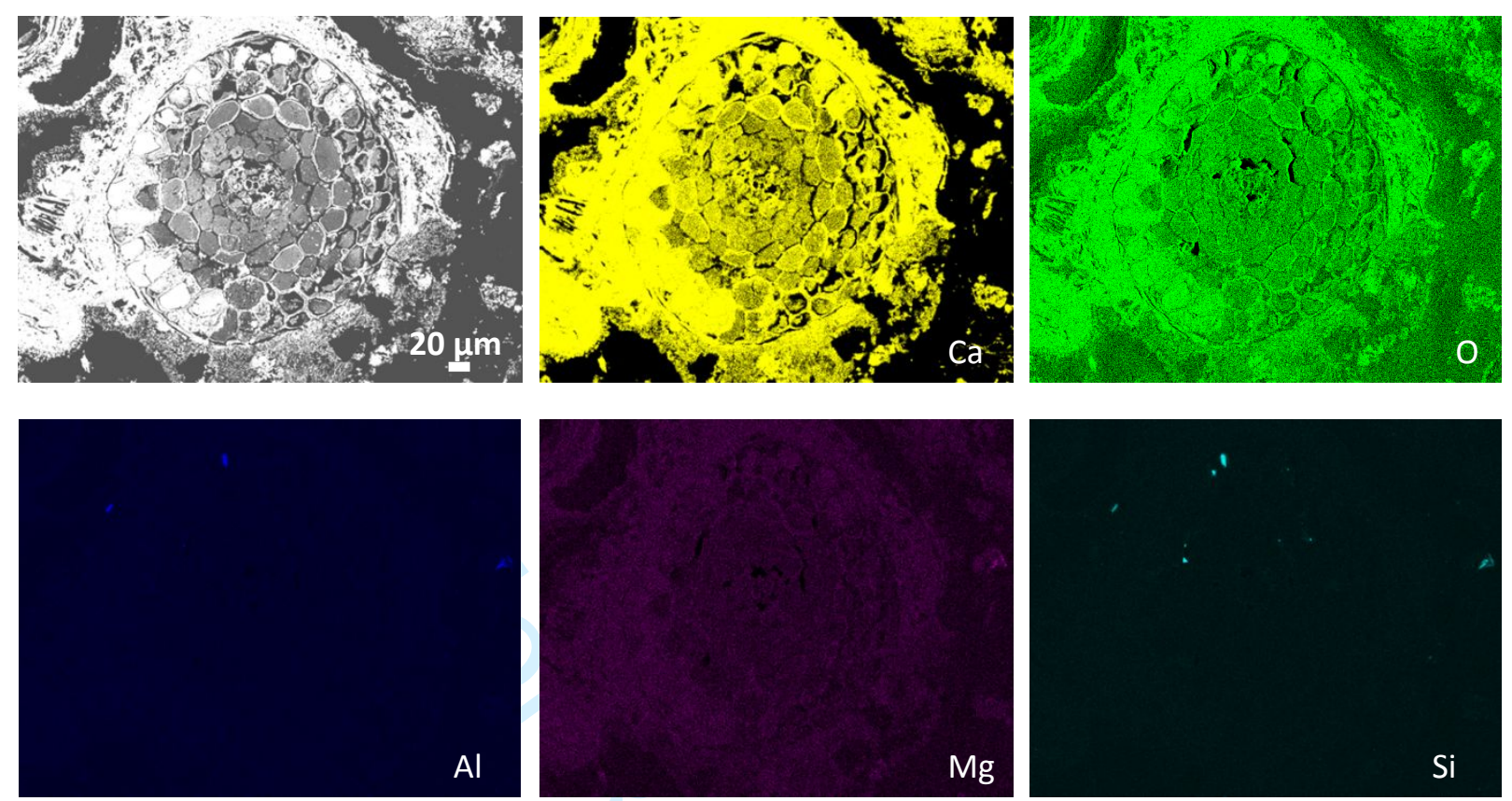

(b)
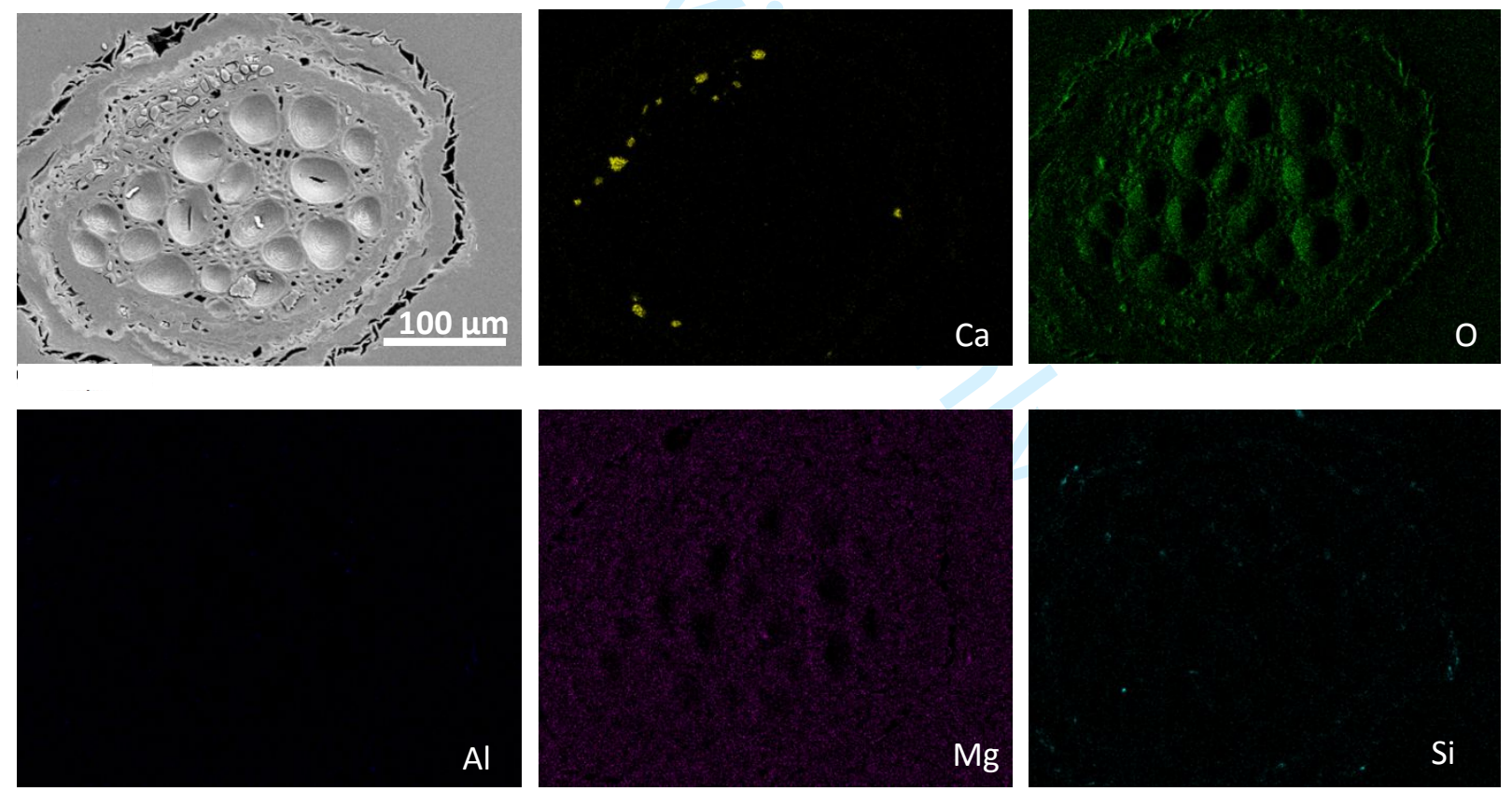

50

51

52

53

54

55

56

57

58

59

60 
(a)

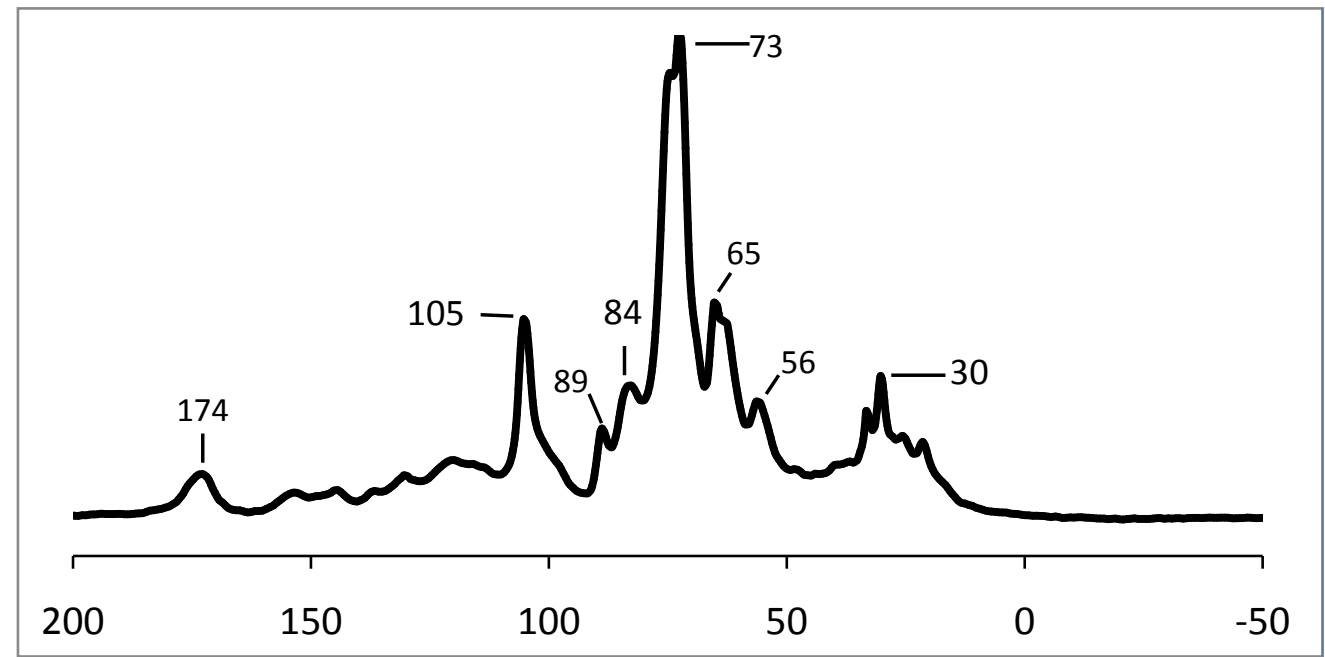

(b)

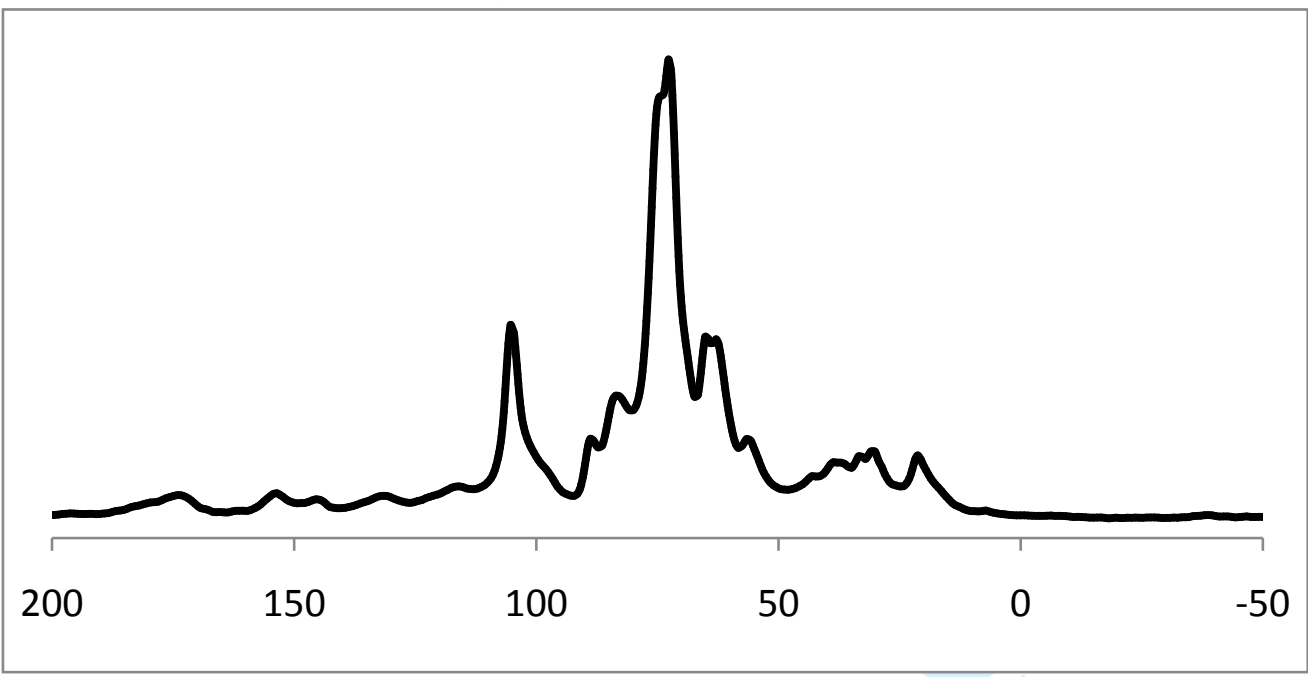

(c)

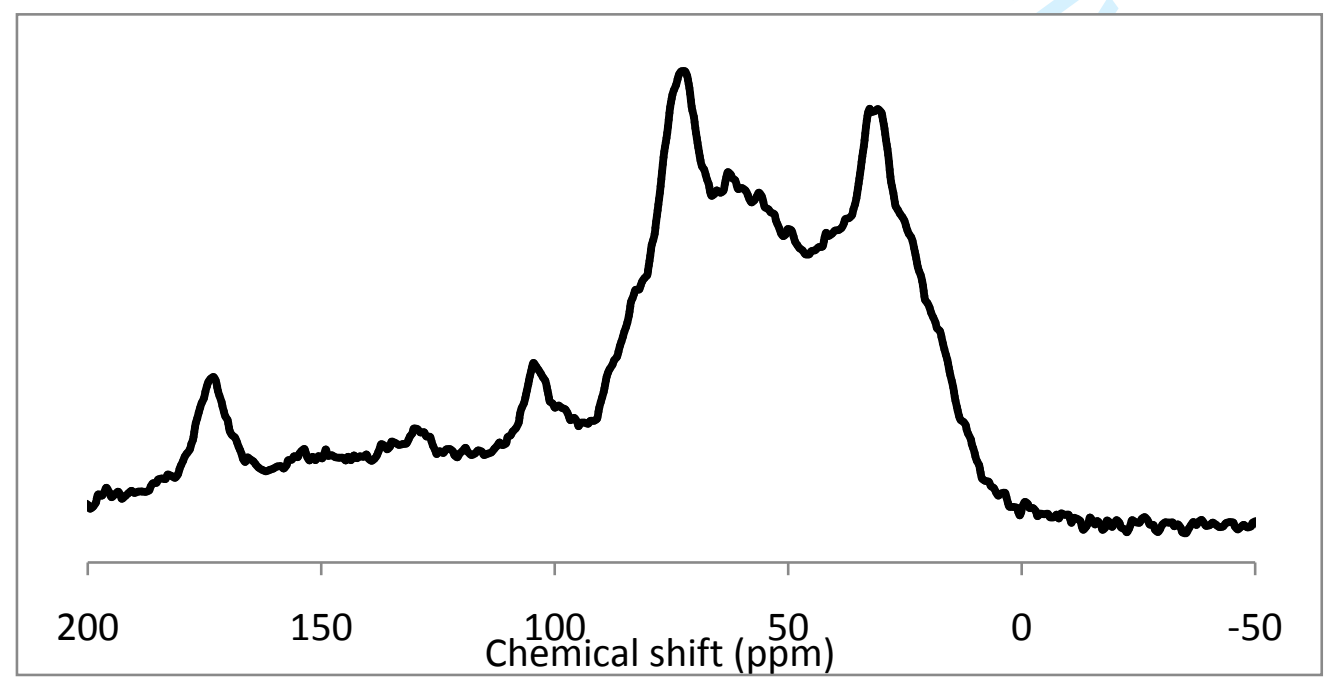




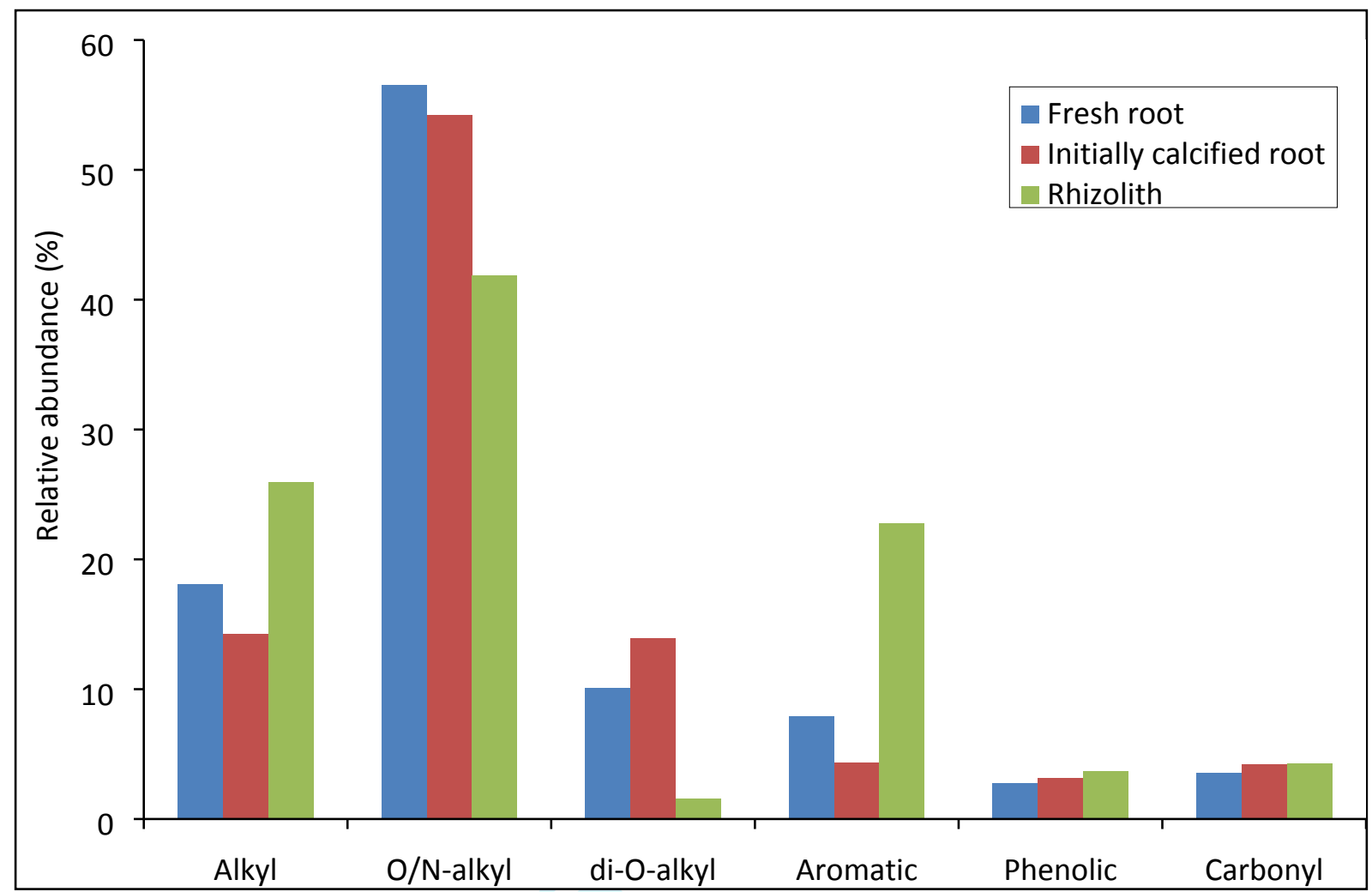



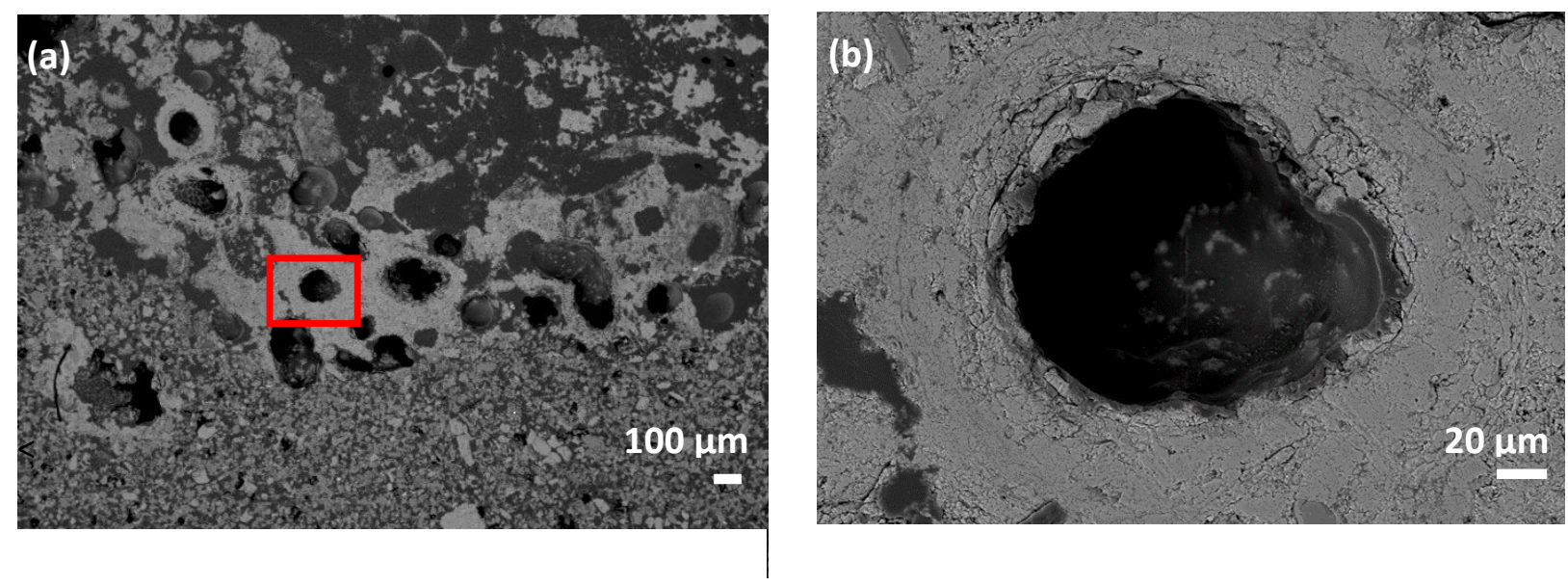

Supp. Fig. 1. Scanning electron micrographs showing the structure of rhizolith collected at $2.15 \mathrm{~m}$ depth in cross section. The zone highlighted in red in panel (a) was enlarged for better visualization of the rhizolith internal structure (cf. panel (b)). 
Page 61 of 61

Geobiology

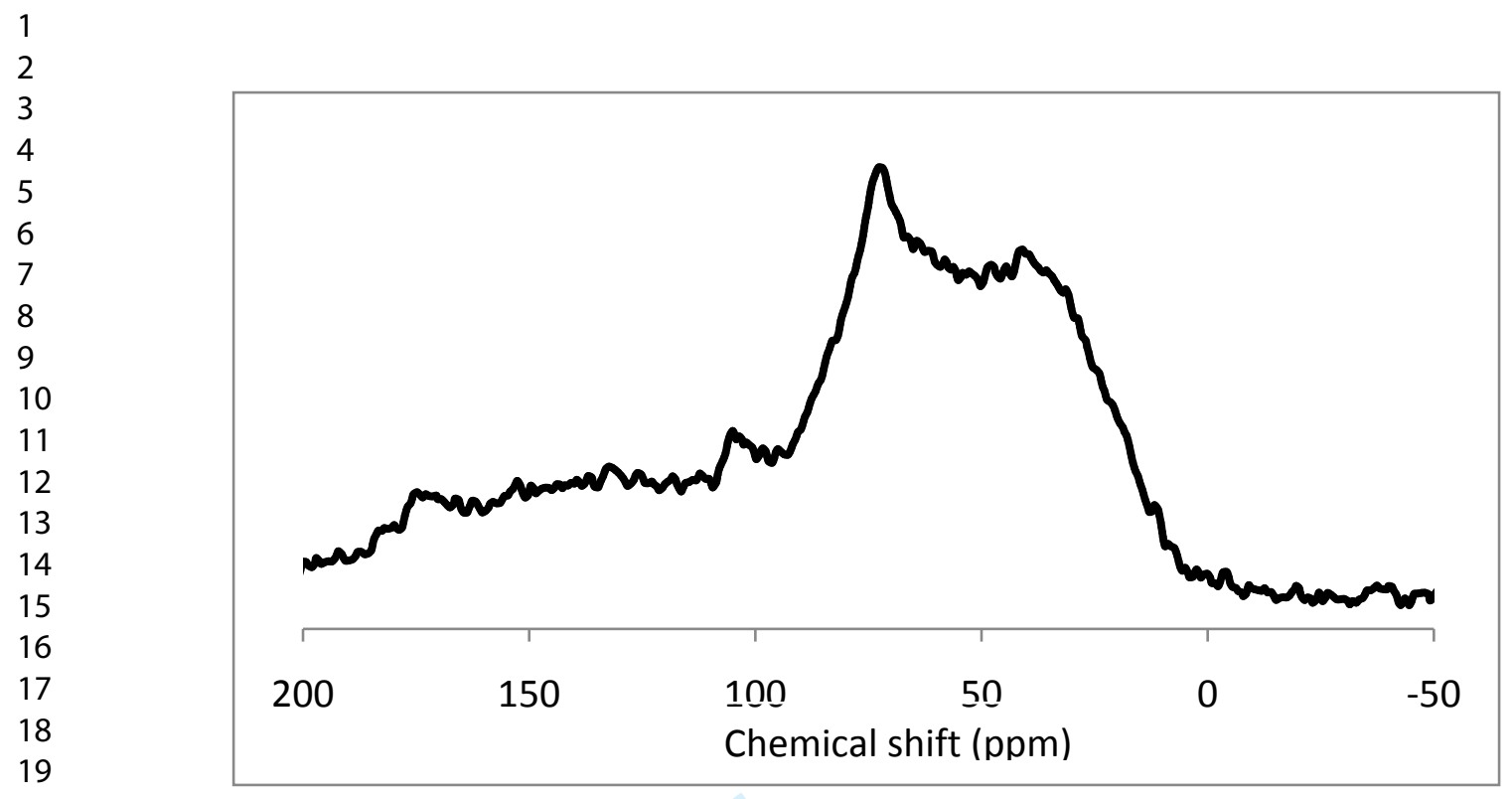

Supp. Fig. $2 .{ }^{13} \mathrm{C}$ NMR spectrum of rhizolith collected at $2.15 \mathrm{~m}$ depth in Nussloch (SW Germany).

22

23

24

25

26

27

28

29

30

31

32

33

34

35

36

37

38

39

40

41

42

43

44

45

46

47

48

49

50

51

52

53

54

55

56

57

58

59

60 